NEWS

\title{
Diseased cells fail to win approval
}

\section{Consent form signed by clinic's donors falls short of 'high ethical standards' set by the NIH.}

In the latest obstacle to expanding the number of embryonic stem-cell lines eligible for US federal funding, a National Institutes of Health $(\mathrm{NIH})$ committee has unanimously rejected dozens of cell lines carrying mutations for specific diseases. The committee of advisers to NIH director Francis Collins ruled that the extremely broad language in the informedconsent form signed by donating couples does not meet ethical requirements.

"We are sorry about the decision about these lines," says Collins, who must sign off on the 10 June vote. "Many of them contained interesting single-gene mutations, but if we have guidelines we have to stick to them in order to maintain credibility."

Embryonic stem-cell lines that carry the recipe for an inherited disease are valued by researchers. This is because as the cells mature and specialize they should offer a detailed view of how a disease manifests itself in the earliest stages of life, and provide targets for drug

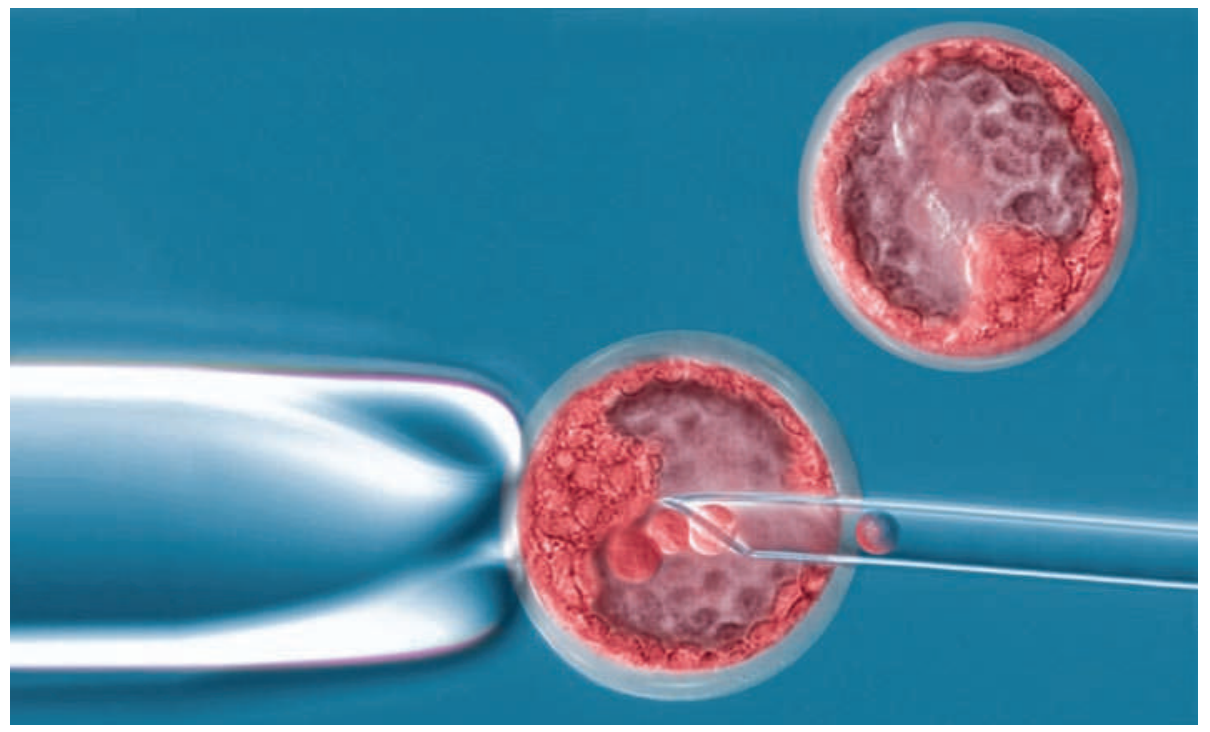

Cells taken from embryos to test for inherited diseases can be used to generate cell lines for research. testing. Of 67 lines so far approved for federal funding, just one - for Marfan syndrome, a rare connective-tissue disorder - is explicitly disease-specific.

The 47 lines rejected last week, 42 of which carry mutations for specific diseases, were derived by the Reproductive Genetics Institute (RGI) in Chicago, a private fertility clinic that specializes in preimplantation genetic diagnosis (PGD). During PGD, one or two cells are removed from a very early stage embryo in order to establish whether it carries a particular mutation for an inherited disease; only embryos without the mutation are then implanted

As a private clinic, the RGI was not barred from using exculpatory language, and it did follow the guidelines published by the NIH last July. The guidelines require cells eligible for federal funding to have come from leftover embryos that would otherwise have been discarded, and ban financial inducements to donors. They do not address exculpatory language.

"Our assessment was not that RGI broke the applicable regulatory rules, but rather that their application did not meet the high ethical standards that are appropriate for federal funding of human embryonic stem-cell research," says Jeffrey Botkin, a professor of paediatrics at the into the mother's womb.

The RGI derived roughly 150 disease-specific stem-cell lines from leftover embryos between 2003 and 2008. All the donating couples agreed to the same broad informed-consent language,

"The most valuable human embryonic stem-cell lines are those that model genetic disease." University of Utah School of Medicine in Salt Lake City, who chairs the working group that guided the committee's decision. George Daley, a stem-cell researcher at the Children's Hospital Boston in Massachusetts, says he respects which effectively waived their right to sue the RGI in any forum at any time for reasons "related to our participation in this study". Such wording is deemed 'exculpatory' - meaning it requires people to waive rights that they would otherwise have - and is therefore forbidden under rules governing federally funded research.

The possibility of using the RGI lines in federally funded research arose last year, when the Obama administration lifted a 2001 ban imposed by former president George Bush on federal support for work on new stem-cell lines. the NIH's decision and its ethical basis. But, he adds, "the most valuable human embryonic stem-cell lines are those that model genetic disease, and excluding the RGI lines means a significant lost opportunity to study these diseases." The lines voted down last week include cells carrying mutations that cause Huntington's disease, cystic fibrosis, inherited breast cancer, neurofibromatosis, Duchenne muscular dystrophy, tuberous sclerosis and sickle-cell anaemia.

Clive Svendsen, the director of the Regenerative Medicine Institute at Cedars-Sinai
Medical Center in Los Angeles, California, notes that work on most of the RGI lines has not been published, leaving their particular value unknown. But if they are biologically sound, he says, "they are very valuable". In that situation, "is this detrimental to the research community? Clearly the answer is yes".

Botkin told the committee that "if feasible", getting the embryo donors to sign new consents, using a form with the offending language removed, "would adequately address our concerns". Oleg Verlinsky, the RGI's chief executive, told Nature that he has attempted to contact two of the consenting couples through their referring physicians. Both doctors refused to provide the couples' addresses, citing federal privacy law. Last week Verlinsky pronounced the situation "a nightmare".

But he says that he will persevere. "We will try. We may get a few lines through out of the 47." The RGI had begun applications for another 31 disease-specific cell lines. But, Verlinsky says, "there's no point" in continuing with that process now, because the additional lines used the same consent form.

Last December, Collins restricted federal funding for 27 lines from a Harvard University lab in Cambridge, limiting their use to work on pancreatic formation with the long-term goal of diabetes treatment. The consent form was an issue in this case as well: it had stipulated that the lines would be used for this purpose.

Meredith Wadman 